\title{
Oil Palm Boom and Farm Household Diets in the Tropics
}

\author{
Kibrom T. Sibhatu* \\ Department of Agricultural Economics and Rural Development, University of Goettingen, Goettingen, Germany
}

Farm households in the tropics are rapidly expanding oil palm monocultures, mainly at the expense of rainforests, agroforests, and traditional croplands. Although monetary gains and ecological consequences of such changes in land-use have been extensively documented, little is known about nutritional and dietary impacts on farm households despite those households being the most affected by nutritional problems. Here, this research gap is addressed with a 2-year panel data of farm households from Jambi province in Indonesia, a hot spot of tropical rainforest conversion into oil palm plantation. I use endogenous switching regression to better account for selection bias and obtain counterfactual outcomes. Results show high levels of undernourishment and micronutrient inadequacy in farm households in Jambi. Non-adopters are more likely to be undernourished and micronutrients deficient, consume less diverse foods, and

OPEN ACCESS

Edited by:

Amy lckowitz,

Center for International Forestry

Research, Indonesia

Reviewed by:

Thierry Brunelle,

Centre de coopération internationale en recherche agronomique pour le développement (CIRAD), France

Wil De Jong,

Kyoto University, Japan

${ }^{*}$ Correspondence:

Kibrom T. Sibhatu

ksibhat@uni-goettingen.de

Specialty section:

This article was submitted to Land, Livelihoods and Food Security, a section of the journal Frontiers in Sustainable Food Systems

Received: 17 April 2019

Accepted: 28 August 2019 Published: 13 September 2019

Citation: Sibhatu KT (2019) Oil Palm Boom and Farm Household Diets in the Tropics. Front. Sustain. Food Syst. 3:75. doi: 10.3389/fsufs. 2019.00075 eat low quantities of fruits and vegetables. The counterfactual analysis shows that oil palm adoption leads to significantly greater household dietary diversity, higher calorie consumption, more fruit and vegetable consumption, and higher food expenditure in farm households. These positive dietary impacts are observed irrespective of whether households belong to transmigrant or local communities. Panel regression results further show that oil palm cultivation reduces the prevalence of undernourishment and, at the same time, increases the mean probability of adequacy of consumed fruits and vegetables and micronutrients. This impact, leading to better diets, however, is complex and not straightforward; several socioeconomic, demographic, and farm factors have different dietary impacts for adopters and non-adopters. The findings highlight important policy implications: farm households adopt and expand land-uses that provide greater dietary benefits. Thus, policy-makers interested in maintaining the tropical rainforests, regulating oil palm plantations, and tackling nutritional deficiencies in the rural tropics should not overlook these dietary benefits for farm households.

Keywords: land-use change, oil palm, dietary diversity, food security, farm households, Indonesia, tropical rainforests

\section{INTRODUCTION}

Changes in land-use have been altering ecosystems and livelihoods throughout history. Recent years have witnessed a massive expansion of oil palm monocultures in the tropics of Asia, mainly at the expense of rainforests, agroforests (timber and jungle rubber), and traditional crops such as rubber and rice (Daulay et al., 2016; Drescher et al., 2016; Byerlee et al., 2017). Although large-scale commercial plantations used to dominate this massive expansion, farm households are 
also adopting intensively managed oil palm monocultures at a high rate (Byerlee and Viswanathan, 2018). Current estimates show that smallholder farmers account for 40 to $50 \%$ of the total oil palm plantation areas (Euler et al., 2016; Byerlee et al., 2017). This crop's rapid expansion in farm households has fostered a growing body of literature focused mainly on the associated negative ecological impacts and socioeconomic implications for those households.

The negative ecological impact of farm households' oil palm expansion has been extensively documented. It is particularly associated with deforestation, ecosystem erosion, biodiversity loss, soil erosion, and greenhouse gas emission (Foster et al., 2011; Clough et al., 2016; Drescher et al., 2016). Mixed findings are reported on the socioeconomic implications. While some studies argue that oil palm expansion causes social conflicts on local communities (Overbeek et al., 2012; Krishna et al., 2017b; Hidayat et al., 2018), numerous other studies suggest that farm households' adoption of the crop contributes to alleviate poverty and improve households' income and living standards (Dewi et al., 2005; Sunderlin et al., 2008; Tscharntke et al., 2010; Euler et al., 2016, 2017). However, a closer look at those studies examining the impact of oil palm cultivation on growers' welfare reveals two critical shortcomings, strikingly vital for research and policy-making. First, the vast majority of these studies used cross-sectional data and expressed welfare benefits in terms of money and asset accumulation. Second, those studies have hardly looked at possible nutritional and dietary effects of oil palm adoption in farm households (Euler et al., 2017; Chrisendo et al., 2019). From a development-policy standpoint, however, longitudinal evidence and welfare analyses that go beyond monetary profits are critically important, particularly in rural areas of the tropics where the highest concentration of malnourished farm households are found. In this study, I contribute to the literature by addressing these two shortcomings.

In particular, using unique panel household survey data from the tropical rainforest areas of Indonesia and regression models that better account for selection bias, I examine the dietary impacts of oil palm adoption in farm households that have chosen to grow the crop in comparison to other farmers that do not. Examining the dietary impact of oil palm adoption in farm households of the tropics is important for several other reasons. First, despite significant progress in recent decades, nutritional deficiencies still pose serious problems in farm households; for instance, about $40 \%$ of the Indonesian population is affected by undernutrition and micronutrient malnutrition, and majority of the affected are farm households (Isabelle and Chan, 2011; FAO and WHO, 2014; Ickowitz et al., 2016). Second, tens of millions of farm households in the tropical areas continue to adopt oil palm (Byerlee et al., 2017). This increasing adoption by smallholder farmers is despite the crop, which yields the highest output per ha of all oil crops (FAO, 1990), requiring an expensive initial investment, managerial skills, and a switch to more capital-intensive farming practices (Euler et al., 2017). Third, oil palm cultivation has been seen as an opportunity for fighting against rural poverty and food insecurity in several Southeast Asian countries, including in Indonesia (Zen et al., 2005; FAO and WHO, 2014). Therefore, understanding how to make such an expensive agricultural strategy to be nutritionsensitive and contribute to improving farm households' nutrition is vital for research and policy-making.

This study is based on a 2-year panel data from the Jambi province on the island of Sumatra. Indonesia is the largest oil palm-producing and-exporting country in the world (FAO, 2018), despite also boasting the highest deforestation rate (Margono et al., 2014). Jambi province is a study area of particular interest, having undergone a significant conversion of primary forests to oil palm plantations over the last few decades (Wilcove et al., 2013; Gatto et al., 2015). The province, like other rural areas in Indonesia, has high levels of underweight and stunted children, poor household dietary diversity, and pervasive micronutrient deficiencies (FAO and WHO, 2014). Additionally, the availability of a unique panel dataset of farm households from Jambi, as part of a larger interdisciplinary research project (Drescher et al., 2016), inspired the pursuit of this study. These data allow differentiating between adopters and non-adopters as well as to calculate various household-level dietary indicators, including dietary diversity scores, quantities of fruits and vegetables consumed, calories consumed, and the measures of food and micronutrient adequacies.

Rural markets in Indonesia are poorly developed (Ickowitz et al., 2016), but plantation farmers in Jambi hardly cultivate food crops for their own consumption (Sibhatu et al., 2015; Euler et al., 2017). This has significant implications in terms of food and nutrition security. Those plantation farmers heavily depend on agricultural cash income to purchase adequately diverse foods from such imperfect markets (Sibhatu et al., 2015; Sibhatu and Qaim, 2018), which consequently makes them vulnerable to substantial income and price shocks. Moreover, cultivating perennial and non-food commercial crops-that do not directly add to household dietary diversity through own consumption, are claimed to compete for resources (e.g., land) with other food crops that in turn negatively affects food availability and increase food prices ( $\mathrm{Li}, 2015)$. Given these serious implications, I hypothesize that adopting oil palm worsens diversity and quality of diets, increases the prevalence of undernourishment, and aggravates micronutrient inadequacies in farm households. Whether oil palm adoption in farm households helps their diets meet the minimum adequacy level and contributes to reducing the prevalence of undernourishment is an empirical question that I also seek to answer with this study.

\section{MATERIALS AND METHODS}

\section{Research Area}

This study is conducted in the lowlands of Jambi province, Sumatra, Indonesia, as part of the CRC990/EFForTS investigating ecological and socioeconomic changes associated with the transformation of lowland rainforest into agricultural systems (Drescher et al., 2016). In this subsection, I briefly discuss the socio-environmental and agricultural nature in Jambi in order to set the background for the study. Jambi province is home to diverse ethnic groups and multiple indigenous languages and dialects. It is part of the tropical areas historically covered by rainforests (Foster et al., 2011; Clough et al., 2016). 
Forest reserves and national parks in Jambi currently house some endangered wildlife, among them, the Sumatran orangutan, tiger, and elephant (Luskin et al., 2014). The humid tropical climate in the province is conducive to rich biodiversity and plantation crops, such as timber, rubber, and oil palm.

History of deforestation and logging in Jambi and other regions of Indonesia date back over a century, with the cultivation of timber and rubber and, more recently, with a massive expansion of oil palm monoculture. Between 1990 and 2010, commercial plantation expansion, mining, and logging activities had caused a loss of 2.65 million ha of primary forest in Jambi, approximately $43 \%$ of its total forest area (Margono et al., 2014).

Agroforestry (timber and jungle rubber) and commercial plantations (rubber and oil palm) are the most important income sources for the population of Jambi. Rubber was the most dominant crop before being recently overtaken by oil palm (Figure 1). The areas under rubber decreased by half since 2010. Contrarily, oil palm plantation, first introduced in the region through government support programs, kept expanding. In the 1980s, farm households started to cultivate oil palm with subsidized contract programs (Rist et al., 2010; Gatto et al., 2017). While subsidization stopped after 1999, independent adoption continued to grow steadily (Susanti and Budidarsono, 2014; Euler et al., 2017). Currently, Jambi is the sixth top producer of crude palm oil in Indonesia, with more than 200,000 smallholder farm households and $\sim 700,000$ ha of oil palm plantation (FAO, 2018). Important to note is that some forest cover is still available in Jambi that could be converted into oil palm plantation at any time. Thus, understanding why farm households chose to adopt oil palm is of paramount importance to promote environmentfriendly production practices and improve the livelihoods of farmers and rural laborers in Jambi and similar areas worldwide.

\section{Panel Household Survey}

To examine the dietary impacts of oil palm adoption in farm households, the analysis draws upon a 2-year panel data from Jambi province. The two farm household surveys were implemented during the dry seasons in 2012 and 2015. A multistage random-sampling approach was applied in order to select a representative sample. In the first stage, all regencies covering the province's tropical lowland areas, namely Batanghari, Bungo, Muaro Jambi, Sarolangun, and Tebo, were purposely selected. From these regencies, 20 districts were selected randomly. Likewise, in each district, two villages were selected randomly; that is, 40 villages in total.

Additionally, five other villages were included in the sample to cover some areas where other CRC990/EFForTS' subprojects had conducted ecological experiments. At the last sampling stage, between 6 and 25 farm households from each village (depending on the village population size) were randomly selected. In total, 700 households were selected and interviewed. Only those households owning agricultural land in the last 5 years were included since oil palm experiences yield-delay for about 4 years between establishing new plantation and harvesting the first fruit bunches. Each household interviewed in 2012 was revisited in 2015. The attrition rate between the two surveys was $6 \%(41$ observations) because of outmigration (56\%), refusal to be reinterviewed $(24 \%)$, and the death or old age of respondents (20\%). Moreover, a few households were dropped due to missing data. To reduce the effect of attrition, those farmers who were not available in 2015 were replaced with other households from the same village that was also randomly selected.

The sample households are relatively specialized farmers in plantation crops, either rubber, oil palm, or both. Some of the respondents produce food crops like rice and maize. Moreover, few of them also grow horticultural crops, rear livestock (mainly chicken) and supplement with aquaculture production.

Data were collected using a structured questionnaire and through face-to-face interviews by carefully-trained enumerators in Bahasa Indonesia. Pre-testing was carried out to assess the questionnaire's clarity. The panel dataset contains a wide range of information, including household demographics, socioeconomic characteristics, farm activities, and food and non-food consumption. The food consumption section includes detailed information related to the type and quantity of consumed foods over the past week. While most of the data were collected by interviewing the household head or the spouse, the information about food consumption was collected by interviewing the persons responsible for buying and preparing food, often the wife or an adult daughter. In total, detailed quantitative information of 120 food items was collected, which allowed for the calculation of the household dietary indicators explained in the following sub-section.

\section{Dietary Indicators}

The main aim of this study is to examine the effects of oil palm adoption on household dietary outcomes, for which I use household dietary diversity (HDDS), daily consumption of calories, daily consumption fruits and vegetables; and annual food expenditure per adult equivalent (AE) as the primary outcome variables. To better understand the implications for food and nutrition security, I also use dichotomous dependent variables, indicating whether household diets met the minimum adequacy level of consumed fruits and vegetables, calories, as well as iron, zinc, vitamin $\mathrm{A}$, and an average of these three micronutrients (iron, zinc, and vitamin A). I focus on these three micronutrients since their deficiency affects millions of people, particularly women and children (Black, 2014). All dietary indicators are derived from a quantitative 7-day recall of food intake that has already been consumed by the household members. Food waste and foods consumed outside the home are not included in the calculation of the dietary outcomes. Recent studies have shown household dietary indicators based on a quantitative 7-day recall period of food consumption are strongly correlated with individual-level indicators constructed on $24 \mathrm{~h}$ recall period (Sununtnasuk and Fiedler, 2017; Fongar et al., 2019).

Diet diversity is often used to indicate food security in terms of both availability and access (Ruel, 2003). I calculate a nine food groups of HDDS, based on those used for the Minimum Dietary Diversity for Women and which contribute strongly to micronutrient adequacy (Martin-Prével et al., 2015; FAO and FHI 360, 2016). Food groups that have little or undesirable 


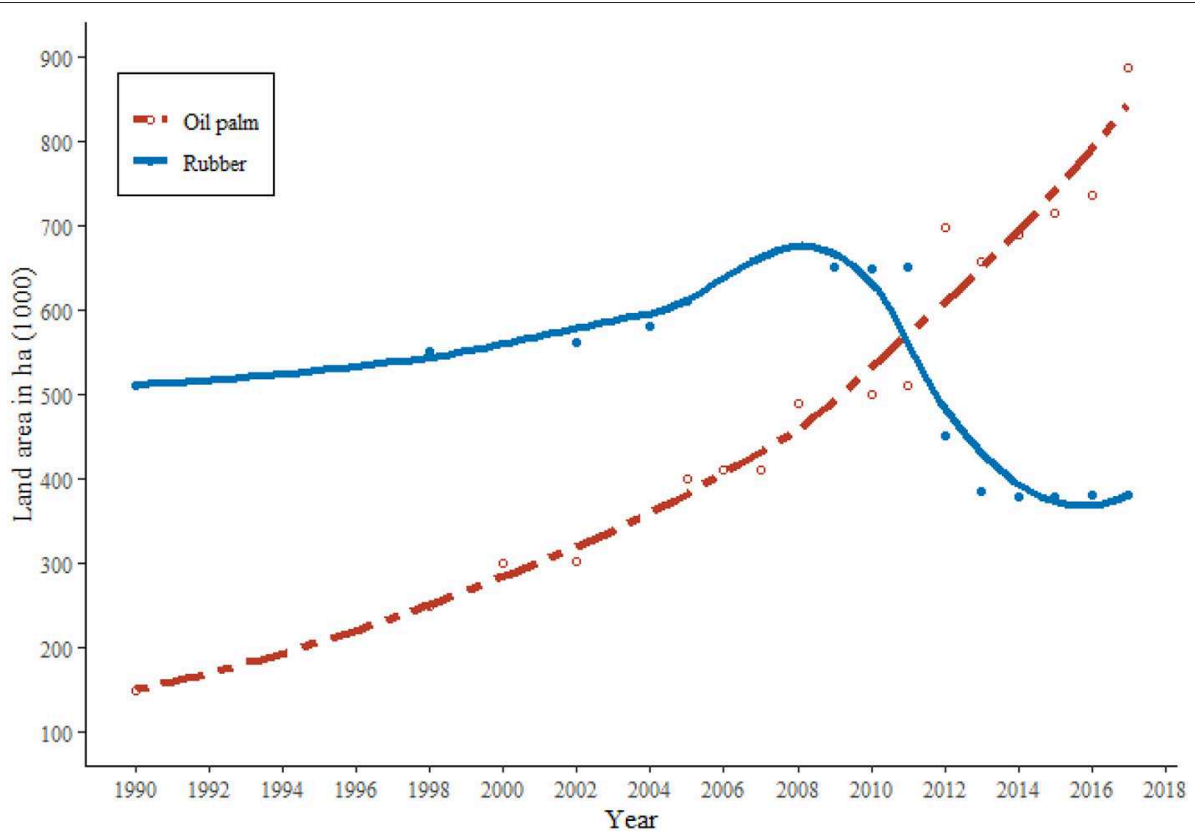

FIGURE 1 | Rubber and oil palm plantation areas in Jambi province, between 1990 and 2017. Author's presentation based on data taken from the Tree Crop Statistics of Indonesia yearbooks (BPS, 2017, 2018; DJP, 2017).

nutritional and health effects when consumed in large quantities are excluded (sugars and sweets, oils and fats, and condiments) from HDDS. Food consumption expressed in terms of calories is also a standard indicator used to assess food availability at the household-level (de Haen et al., 2011; Frelat et al., 2016; Sibhatu and Qaim, 2017). Using Food Composition Tables in Indonesia (Berger et al., 2013), the quantities of food items consumed are converted into calories. The USDA National Nutrient Database for Standard Reference (USDA, 2005) is used for a few food items not listed in the Indonesia Food Composition Table. The quantities of calories are adjusted by $\mathrm{AE}$ to account for differences in household demographic structure, such as age and gender. Besides, annual food expenditure is used as an additional outcome variable, as it is also one of the commonly used indicators of food security (de Haen et al., 2011; Lo et al., 2012). Annual food expenditure is also adjusted by the consumer price index for Indonesia across survey rounds and by $\mathrm{AE}$. Alcohol, drinking water, and condiments are omitted in the food expenditure calculation.

In the same procedure that I calculate calories, quantities of the food items consumed are first converted into equivalent micronutrient consummation per AE. After that, the households are divided into two groups of food and micronutrient adequacy status, based on the estimated daily energy, fruits and vegetables, and micronutrient requirements of a male adult with normal physical activity. Households are classified as food abundant if the quantities of calories they consumed are above the estimated minimum threshold of 2,400 kcal per AE a day (FAO, 2001). For fruit and vegetables as well as for micronutrients consumed, the internationally recommended quantities are $400 \mathrm{~g}$ for fruits and vegetables, $18 \mathrm{mg}$ for iron, $15 \mathrm{mg}$ for zinc, and $625 \mu \mathrm{g}$ retinol equivalents for vitamin A per AE a day (FAO et al., 2004). Following Hatløy et al. (1998), adequacy is expressed for each dietary indicator in terms of a dummy variable, being " 1 " if actual consumption is equal to or above the recommended level, and being " 0 " otherwise. Moreover, mean micronutrient adequacy is calculated for each household by averaging the adequacy indicators for iron, zinc, and vitamin A.

\section{Covariates}

Several other factors may influence the quality and diversity of diets in smallholder farm households. Moreover, the dietary impact pathways of oil palm cultivation might depend on the mediation of socioeconomic, cultural, farm, and demographic factors (Chrisendo et al., 2019). I estimate all regression models (see Econometric Analysis subsection) including farm, socioeconomic and demographic characteristics, such as farm and household sizes, credit access, as well as age, ethnicity, and the education level of the household head as covariates. These covariates may influence not only the adequacy of diets and micronutrients, but also the choice of what and how much to produce, and would hence mediate the impact of oil palm cultivation on household diets.

\section{Econometric Analysis}

In this subsection, I present the econometric models estimated in this paper, namely the endogenous binary switching regression. A simple linear panel estimation that assumes a set of explanatory variables have the same impact on adopters and non-adopters may not be appropriate in this study for at least two reasons. First, many of the oil palm farmers - in the dataset that I use in this study-acquired the plantations through a transmigration 
program (Euler et al., 2017). This implies that sample selection bias is possible in this dataset, and thus, several of the covariates might have different dietary impacts to adopters and nonadopters (Krishna et al., 2017a). Second, for the economic significance of the estimated coefficients, a challenge is that observed and unobserved factors might affect oil palm cultivation and household diets simultaneously, such as risk preferences, entrepreneurship and farm management knowledge, and skills. Thus, identifying the impacts of oil palm adoption on household diets requires dealing with such observable and unobservable characteristics as well as controlling for selection bias. To deal with these two methodological issues, I apply endogenous binary switching regression. Endogenous binary switching regression in a counterfactual framework allows identifying the effects on dietary outcomes in each of the two groups, instead of pooling the adopters and non-adopters in one regression model.

Modeling of the effects of oil palm adoption on dietary indicators under the endogenous specification framework is applied in two stages. First, the decision to adopt oil palm (adoption equation) is estimated using a probit model, in which the equation is specified as

$$
O P_{i}^{*}=Z_{i} \beta+\varepsilon_{i} \quad \text { with } O P_{i}=\left\{\begin{array}{cc}
1 & \text { if } O P_{i}^{*}>0 \\
0 & \text { if otherwise }
\end{array}\right.
$$

where $\boldsymbol{O} \boldsymbol{P}_{\boldsymbol{i}}^{*}$ denotes a latent variable for household $\boldsymbol{i}$ 's adoption of oil palm; $\boldsymbol{O} \boldsymbol{P}_{\boldsymbol{i}}^{*}=\boldsymbol{1}$ if a household cultivates oil palm and $\boldsymbol{O} \boldsymbol{P}_{\boldsymbol{i}}^{*}=\boldsymbol{O}$ otherwise. $\boldsymbol{\beta}$ is a vector of parameters to be estimated; $Z_{i}$ is a vector of control variables explaining the possibility of being an oil palm household. $\varepsilon_{\boldsymbol{i}}$ denotes the random error.

Second, panel linear regressions (outcome equations), with selection bias correction and conditional on adoption decision, are used to examine the relationship between the dietary indicators and a set of explanatory variables (Equations 2 and 3 ). Specifically, the outcome regression equations are specified in two separate equations-one for oil palm adopters and another for the non-adopters, and the equations estimated are such that:

$$
\begin{array}{ll}
N_{a i}=X_{a i} \beta_{a}+v_{a i}, & \text { if } O P_{i}=1 \\
N_{n i}=X_{n i} \beta_{n}+v_{n i}, & \text { if } O P_{i}=0
\end{array}
$$

where subscript $\boldsymbol{a}$ and $\boldsymbol{n}$ denote adopters and non-adopters, respectively. $N$ represents the household diet indicators (i.e., HDDS, consumption of calories, grams of fruits and vegetables, and annual food expenditure). $\boldsymbol{N}_{\boldsymbol{a} i}$, refers to adopters (treatment group) and $\boldsymbol{N}_{\boldsymbol{n} \boldsymbol{i}}$, to non-adopters (control group). $\boldsymbol{\beta}_{\boldsymbol{a}}$ and $\boldsymbol{\beta}_{\boldsymbol{n}}$ are vectors of parameters to be estimated. The error terms are $\boldsymbol{v}_{\boldsymbol{a}}$ and $\boldsymbol{v}_{n}$.

Equation (1), the adoption equation, decides which of the two types of groups (adopters or non-adopters) is applicable. Equations (2) and (3) describe the variables of concern (dietary indicators) in each of the two groups. The error terms $\boldsymbol{v}_{\boldsymbol{a} i}, \boldsymbol{v}_{\boldsymbol{n} i}$, and $\boldsymbol{\varepsilon}_{i}$ are assumed to have a trivariate normal distribution with a mean of zero. In particular, as the error term $\boldsymbol{\varepsilon}_{\boldsymbol{i}}$ in Equation (1) is correlated with the error terms in Equations (2) and (3), the expected values of $\boldsymbol{v}_{\boldsymbol{a} i}$ and $\boldsymbol{v}_{\boldsymbol{n} i}$ conditional on the sample selection should be non-zero (Lokshin and Sajaia, 2004; Wooldridge,
TABLE 1 | Conditional expectations and treatment effects.

\begin{tabular}{llll}
\hline Household type & Adopters & Non-adopters & Treatment effect \\
\hline Adopters (A) & (a) $E\left(N_{a} \mid O P=1\right.$ & (c) $E\left(N_{n}\right) \mid O P=1$ & $A_{S} N=(a-c) A A T$ \\
Non-adopters (NA) & (d) $E\left(N_{a} \mid O P=0\right.$ & (b) $E\left(N_{n}\right) \mid O P=0$ & $N A_{S} N=(d-b) A T U$
\end{tabular}

Cells (a) and (b) denote the diet indicators that are observed in a sample; cells (c) and (d) denote the counterfactual diet indicators.

$E$ is the expected operator.

$O P=1$ if the household is an adopter of oil palm; $O P=0$ if the household is non-adopter of oil palm.

$N_{a}$ is diet indicators for adopters; $N_{n}=$ dietary indicators for non-adopters.

$A_{S} N$ and $N A_{S} N$ denote the expected diet indicators $(N)$ effects of oil palm adoption for those households randomly chosen from the adopters and non-adopters, respectively. $A T T$ is the average treatment effect on the treated; ATU is the average treatment effect on the untreated.

2010). In simple words, statistically significant and non-zero coefficients of correlation of the error terms indicate that there was selection bias in adopting oil palm in Jambi; otherwise, no sample selection bias.

The endogenous binary switching regression is estimated using full information maximum likelihood estimation. And for a maximum likelihood estimation to be robust, exclusion restrictions should be applied (Di Falco et al., 2011). I use altitude above sea level of the household residence as a selection instrument based on a falsification test. I use altitude above sea level as a selection instrument because, in the low altitudes of Jambi, altitude was found to be affecting oil palm adoption, but not household income and consumption expenditure (Krishna et al., 2017a). A variable (altitude above sea level of the household residence) is considered a valid selection instrument if it affects the decision to implement a particular farming system (statistically significant coefficients for oil palm adoption) but does not affect coefficients in outcome equation (statistically insignificant coefficients of the dietary indicators) (Di Falco et al., 2011).

In order to estimate and compare the impact of growing oil palm on the dietary outcomes of the adopters and non-adopters, I also use the endogenous switching regression model to obtain counterfactual dietary outcomes of each group. Estimating the counterfactual dietary outcomes enables to estimate the dietary indicators of non-adopters if they had adopted oil palm, or to estimate the dietary outcomes of the adopters if they had disadopted oil palm. Put differently, what the dietary status of the non-adopters would have been if their characteristics (coefficients the explanatory variables) had been the same as the adopters' characteristics, and vice versa. I follow Carter and Milon (2005) to compute the actual and counterfactual dietary outcomes of the adopters and non-adopters presented in Table $\mathbf{1}$.

Boxes $(\boldsymbol{a})$ and $(\boldsymbol{b})$ refer to the observed dietary outcomes $(\boldsymbol{N})$ for adopters and non-adopters, respectively, while boxes (c) and $(\boldsymbol{d})$ refer to the counterfactual dietary indicators. If the non-adopters had adopted oil palm, then the expected effect of oil palm adoption on non-adopters' dietary outcomes $\left(N A_{s} N\right)$ would have been the difference between $(\boldsymbol{d})$ and $(\boldsymbol{b})$. Likewise, the expected effect of oil palm adoption on the adopters' dietary outcomes $\left(\boldsymbol{A}_{\boldsymbol{s}} \boldsymbol{N}\right)$ would have been the difference between $(\boldsymbol{a})$ 
and (c) - had they had dis-adopted oil palm. In econometric terms, the $\boldsymbol{A}_{\boldsymbol{s}} \boldsymbol{N}$ and $\boldsymbol{N} \boldsymbol{A}_{\boldsymbol{s}} \boldsymbol{N}$ are equivalent to the average treatment effect on the treated (ATT) and average treatment effect on the untreated (ATU), respectively (Heckman et al., 2001). In other words, ATT refers to the estimated effect of oil palm adoption on the adopters, while ATU refers to the possible effect of oil palm adoption on the non-adopters.

Finally, I conduct further panel regression analyses to understand the impact of oil palm adoption on the dichotomous variables of households' diets indicating whether these diets met the minimum adequacy level of consumed fruits and vegetables, calories, iron, zinc, vitamin A, and an average of these three micronutrients. As these outcome variables are binary, panel logit regression is used for the estimations.

\section{RESULTS AND DISCUSSIONS}

In this section, I present the key findings. First, I explore the descriptive results. I then focus on the econometric estimation results in the following subsections.

\section{Descriptive Characteristics}

Table 2 presents descriptive statistics for the sample households, disaggregated by year and adoption. The adopters and nonadopters are similar in terms of demographic characteristics, including household size, age, and education. However, there is a significant difference in terms of farm characteristics between the two groups. Adopters cultivate significantly bigger farms with a higher proportion of their land having a formal title than non-adopters. Conversely, non-adopters are less likely to access formal credit services, probably since a significant portion of their land does not have a clear title. In terms of ethnicity, the Melayu - the largest local ethnic group in Jambi-account for the majority of the non-adopters. This is probably linked to their tradition of rubber cultivation (Euler et al., 2017). Adopters own more non-farm businesses (like cafes, small shops, and motorbike repair shops) than non-adopters in 2015. As there is no significant difference in off-farm activities between the adopters and non-adopters, I use the "own business" variable as a proxy for off-farm activities in the regression estimations, which I describe in more detail below.

Table 2 also displays summary statistics of the dietary indicators, outcome variables of interest in this study. A significant difference between adopters and non-adopters is observed for these outcomes variables. On overage, adopters consume significantly more diverse foods, particularly more fruits and vegetables. Approximately, 61 and 51\% of nonadopters consumed more calories than the recommended 2,400 $\mathrm{kcal} / \mathrm{AE}$ a day in 2012 and 2015 respectively, whereas 71 and $67 \%$ of the adopters consumed more than the recommended quantities of calories in 2012 and 2015 respectively. In other words, 39 and $49 \%$ of non-adopters and 29 and 33\% of the adopters in 2012 and 2015 are classified as undernourished, respectively. In 2015, 82\% adopters and 92\% non-adopters consumed less zinc than the recommended amount on average. Furthermore, about 57\% adopters and 69\% non-adopters consumed less iron than the recommended amount in 2015.
Similar results are observed in vitamin A consumption. In sum, these findings on dietary outcomes suggest two valuable lessons. First, there is a high prevalence of undernourishment and micronutrient inadequacy in Jambi, which is similar to the national average (see the Introduction section). Second, between the two types of households, the non-adopters are more likely to be undernourished, consume less diverse foods, and consume inadequate fruits and vegetables and micronutrients on average.

Moreover, Figure 2 depicts the food groups consumed by all respondents over the previous 7-day period. The farmers' diet is mainly composed of cereals and starchy staples, meat and fish, nuts and seeds, and eggs. Organ meat, dairy products, and vitamin A-rich fruits and vegetables are relatively the least consumed groups.

Finally, over the 3 years, the number of oil palm adopters rose by $10 \%$ (from 248 to 272 ). Likewise, the proportion of titled land, access to formal credit, owning non-farm businesses increased in the two groups of adopters and non-adopters, Access to offfarm activities also slightly rose from 2012 to 2015, although no significant difference is observed between adopters and nonadopters. Strikingly, all indicators of household diets were lower in 2015 than in 2012 in both groups. This is because of the global drop in the prices of oil palm and rubber after 2012 (Kubitza et al., 2018).

\section{Factors Affecting Oil Palm Adoption and Household Diets}

I now discuss the econometric results, starting with findings from the endogenous switching regression model estimation. The results are presented in Tables 3, 4, and in Tables A1-A3 of the Supplementary Material. The coefficients of correlation $\left(\boldsymbol{\Sigma}_{\boldsymbol{a}}\right.$ and $\boldsymbol{\Sigma}_{\boldsymbol{n}}$ ), which are displayed in the lower part of Table 3, are significantly different from zero between the adoption (Equation 1) and outcome equations (Equations 2 and 3) in most of the model estimations. This confirms that there is self-selection in adopting oil palm in Jambi, supporting the notion that a panel linear regression estimation is not appropriate for the dataset at hand. Furthermore, the Wald test on the exclusion restriction of the variable "Altitude" is jointly significant (Table 3). Simultaneously, altitude does not have a statistically significant effect on all diet indicators of the adopters (Table A1 in the Supplementary Material). These results confirm that the falsification test is statistically valid and the endogenous switching regression estimation provides robust results.

Columns (1), (4), (7), and (10) of Table 3, which are the estimates from the adoption model explained in Equation (1), show that ethnicity, size of cultivated land, the proportion of titled land, and access to credit services influence oil palm adoption significantly. Ethnically, being a Melayu is negatively and significantly related to oil palm adoption. As mentioned earlier, the Melayu are the local people with the tradition of cultivating rubber, and thus less likely to switch to oil palm cultivation. Clearing rubber and setting up an oil palm plantation is also quite costly. Owning a larger cultivated area and a larger proportion of formally titled land positively and significantly influences the adoption of oil palm. This is expected and 
TABLE 2 | Descriptive differences between adopters and non-adopters of oil palm by year.

\begin{tabular}{|c|c|c|c|c|c|c|}
\hline & \multicolumn{3}{|c|}{2012} & \multicolumn{3}{|c|}{2015} \\
\hline & Adopters & Non-adopters & Difference & Adopters & Non-adopters & Difference \\
\hline \multicolumn{7}{|l|}{ EXPLANATORY VARIABLES } \\
\hline Age of household head (years) & $\begin{array}{l}45.19 \\
(0.77)\end{array}$ & $\begin{array}{l}45.62 \\
(0.59)\end{array}$ & $\begin{array}{c}-0.42 \\
(0.97)\end{array}$ & $\begin{array}{l}47.57 \\
(0.67)\end{array}$ & $\begin{array}{c}47.43 \\
(0.057)\end{array}$ & $\begin{array}{c}0.14 \\
(0.88)\end{array}$ \\
\hline Education level of household head (years) & $\begin{array}{c}7.88 \\
(0.22)\end{array}$ & $\begin{array}{c}7.29 \\
(0.18)\end{array}$ & $\begin{array}{l}0.59^{\star \star} \\
(0.28)\end{array}$ & $\begin{array}{c}7.44 \\
(0.21)\end{array}$ & $\begin{array}{c}7.15 \\
(0.18)\end{array}$ & $\begin{array}{c}0.29 \\
(0.28)\end{array}$ \\
\hline Household owns business (dummy) & 0.24 & 0.19 & 0.05 & 0.35 & 0.22 & $0.13^{\star \star \star}$ \\
\hline Off-farm income ( 1 = yes; 0 = otherwise) & 0.61 & 0.60 & 0.01 & 0.73 & 0.69 & 0.05 \\
\hline Ethnicity: ( 1 = Melayu; 0 = others) & 0.40 & 0.55 & $-0.16^{\star \star \star}$ & 0.43 & 0.53 & $-0.10^{\star \star}$ \\
\hline Cultivated land area (ha) & $\begin{array}{c}5.62 \\
(0.43)\end{array}$ & $\begin{array}{c}3.48 \\
(0.23)\end{array}$ & $\begin{array}{c}2.14^{\star \star \star} \\
(0.48)\end{array}$ & $\begin{array}{c}6.74 \\
(0.69)\end{array}$ & $\begin{array}{c}3.43 \\
(0.25)\end{array}$ & $\begin{array}{l}3.31^{\star \star \star} \\
(0.74)\end{array}$ \\
\hline Share of titled land (\%) & $\begin{array}{c}0.50 \\
(0.03)\end{array}$ & $\begin{array}{l}0.32 \\
(0.02)\end{array}$ & $\begin{array}{l}0.19^{\star \star \star} \\
(0.04)\end{array}$ & $\begin{array}{c}0.54 \\
(0.03)\end{array}$ & $\begin{array}{c}0.37 \\
(0.02)\end{array}$ & $\begin{array}{c}0.17^{\star \star \star} \\
(0.03)\end{array}$ \\
\hline Migrant: ( $1=$ transmigrant; $0=$ otherwise) & 0.44 & 0.24 & $0.20^{\star \star \star}$ & 0.39 & 0.25 & $0.14^{\star \star \star}$ \\
\hline Credit from formal source (dummy) & 0.35 & 0.18 & $0.17^{\star \star \star}$ & 0.47 & 0.28 & $0.19^{\star \star \star}$ \\
\hline Altitude above sea level (meter) & $\begin{array}{l}50.58 \\
(1.58)\end{array}$ & $\begin{array}{l}57.23 \\
(1.34)\end{array}$ & $\begin{array}{c}-6.65^{\star \star \star \star} \\
(2.07)\end{array}$ & $\begin{array}{l}47.51 \\
(1.33)\end{array}$ & $\begin{array}{l}56.80 \\
(1.31)\end{array}$ & $\begin{array}{c}-9.29^{\star \star \star} \\
(1.87)\end{array}$ \\
\hline Household size (number) & $\begin{array}{c}4.19 \\
(0.09)\end{array}$ & $\begin{array}{l}4.21 \\
(0.07)\end{array}$ & $\begin{array}{c}-0.03 \\
(0.12)\end{array}$ & $\begin{array}{l}4.15 \\
(0.09)\end{array}$ & $\begin{array}{c}4.11 \\
(0.08)\end{array}$ & $\begin{array}{c}0.04 \\
(0.12)\end{array}$ \\
\hline \multicolumn{7}{|l|}{ OUTCOME VARIABLES } \\
\hline Household dietary diversity score (HDDS; 9 food groups) & $\begin{array}{c}6.96 \\
(0.07)\end{array}$ & $\begin{array}{l}6.55 \\
(0.06)\end{array}$ & $\begin{array}{l}0.41^{\star \star \star} \\
(0.10)\end{array}$ & $\begin{array}{c}6.94 \\
(0.07)\end{array}$ & $\begin{array}{c}6.57 \\
(0.06)\end{array}$ & $\begin{array}{c}0.36^{\star \star \star} \\
(0.10)\end{array}$ \\
\hline Fruits and vegetables consumed per day (grams/AE) & $\begin{array}{l}679.16 \\
(28.88)\end{array}$ & $\begin{array}{l}541.68 \\
(15.42)\end{array}$ & $\begin{array}{c}137.49^{\star \star \star} \\
(29.86)\end{array}$ & $\begin{array}{l}400.25 \\
(20.60)\end{array}$ & $\begin{array}{l}308.35 \\
(12.82)\end{array}$ & $\begin{array}{l}91.90^{\star \star \star} \\
(22.99)\end{array}$ \\
\hline Calorie adequacy (dummy; $\geq 2,400$ kcal/AE/day) & 0.71 & 0.61 & $0.10^{\star \star \star}$ & 0.67 & 0.51 & $0.16^{\star \star \star}$ \\
\hline Fruits and vegetables adequacy (dummy; $\geq 400$ g/AE) & 0.75 & 0.61 & $0.11^{\star \star \star}$ & 0.37 & 0.24 & $0.13^{\star \star \star}$ \\
\hline Iron adequacy (dummy; $\geq 18$ mg/AE) & 0.57 & 0.39 & $0.18^{\star \star \star}$ & 0.43 & 0.31 & $0.12^{\star \star \star}$ \\
\hline Zinc adequacy (dummy; $\geq 15$ mg/AE/day) & 0.21 & 0.11 & $0.10^{\star \star \star}$ & 0.18 & 0.08 & $0.10^{\star \star \star}$ \\
\hline Vitamin A adequacy ( $\geq 625$ ug RE/AE/day) & 0.56 & 0.41 & $0.15^{\star \star \star}$ & 0.48 & 0.35 & $0.13^{\star \star \star}$ \\
\hline Mean adequacy of iron, zinc and vitamin A (dummy) & 0.44 & 0.30 & $0.14^{\star \star \star}$ & 0.36 & 0.25 & $0.12^{\star \star \star}$ \\
\hline Food expenditure per year (000 IDR/AE) & $\begin{array}{l}7523.43 \\
(285.38)\end{array}$ & $\begin{array}{l}6262.68 \\
(186.77)\end{array}$ & $\begin{array}{c}1260.75^{\star \star \star} \\
(328.30)\end{array}$ & $\begin{array}{c}8202.027 \\
(290.27)\end{array}$ & $\begin{array}{l}6489.72 \\
(161.12)\end{array}$ & $\begin{array}{c}1712.31^{\star \star \star} \\
(307.06)\end{array}$ \\
\hline Observations & 248 & 440 & & 272 & 431 & \\
\hline
\end{tabular}

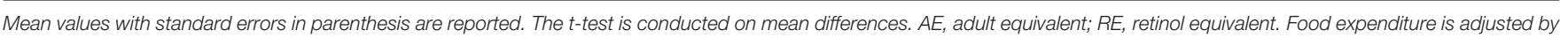
the consumer price index for Indonesia across survey rounds. ${ }^{* \star},{ }^{\star \star \star}$ denote significance at 5 , and $1 \%$ levels, respectively.

plausible, since a larger land size, combined with a formal land title, is vital for long-term agricultural investments such as in oil palm. Having clear land title also allows farmers to use their land as collateral to access rural financial markets or to diversify their off-farm livelihood systems. As one would expect, there exists a positive and significant effect of formal credit access on oil palm adoption, with about $54 \%$ of the cultivated land in oil palm farmers having clear property rights, as compared to the $37 \%$ of non-adopters in 2015 (Table 2).

Now, I discuss the results from the outcomes equation. The estimated effects of the socioeconomic factors on the four outcomes variables are presented in Table 3. In general, the results show that the sign and magnitude coefficients of the covariates are different for the adopters and non-adopters. Some of the covariates that explain the dietary outcomes in the adopters also do not explain that of the non-adopters, and vice versa. This also supports that there was selection bias in the dataset that I use in this study. Moreover, within the dietary indicators, some of the covariates that influence the HDDS, for example, either do not significantly affect or significantly affect calorie consumption and food expenditure in the opposite direction. Thus, this effect difference within the dietary indicators should be taken into consideration when one aims to improve nutrition and food security in vulnerable farm households.

More specifically, unlike in the adopters (Column 2), HDDS of the non-adopters is positively affected by household size, owning a non-farm business, larger cultivated area, and a higher proportion of titled land (Column 3). This is probably implying that nutrition education and awareness are important to improve the diversity of diets in the non-adopters compared to the nonadopters. The results in column (5) show that owning a non-farm business positively and significantly affects the adopters' fruit and vegetable consumption, but no significant effect is observed in the non-adopters. Column (6) shows that household size, taking 


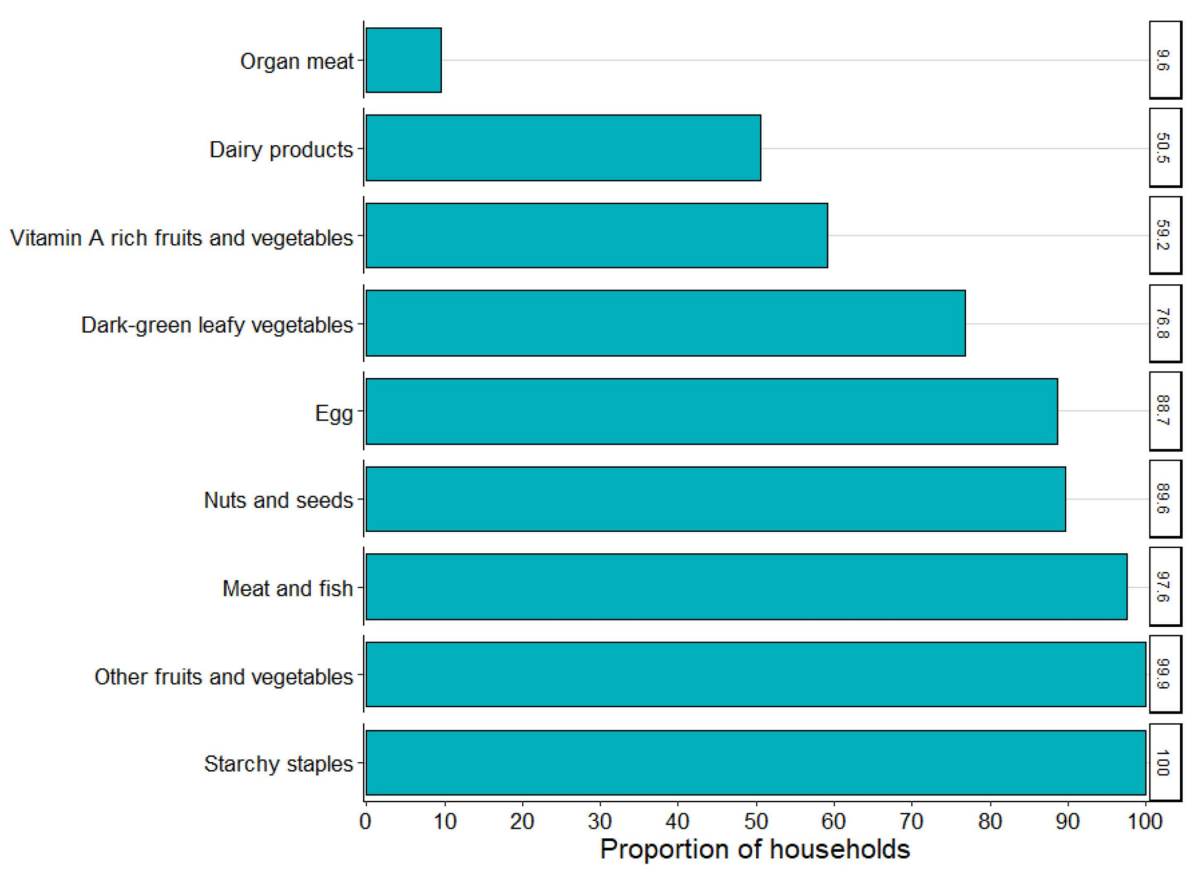

FIGURE 2 | The proportion of households who consumed each food group, 2012 and 2015 combined.

formal credit, a larger cultivated area, and a higher proportion of titled land influences the non-adopters' fruits and vegetables consumed both positively and significantly.

Column (8) shows that owning a non-farm business and a larger cultivated land area seems to positively and significantly affect the consumption of calories in the adopters, possibly suggesting that off-farm income indeed contributes to better household diets. Likewise, column (9) shows that education level of household head, size of cultivated land, and proportion of titled land have a positive and significant effect on the consumption of fruits and vegetables in the non-adopters. As columns (11) and (12) depict, the same set of factors that affect calorie consumption are observed to affect food expenditure to the same effect direction. Important to note is that in both groups, a larger household size affects calorie consumption and food expenditure negatively and significantly. This is to be expected since a family with more mouths to feed is more likely to be with a larger number of economically inactive members, yet spend more on food. Factors related to demographic characters seem to explain the dietary outcomes in the non-adopters than adopters; for example, age and education positively affect food expenditure in the non-adopters, but no significant effect is observed in the adopters.

The year dummy shows that there has been a significant reduction in terms of diversity, calories, the quantities of fruits and vegetables consumed, and food expenditure. As described earlier, this is possibly linked to the global drop in prices of oil palm and rubber. Therefore, the diets of plantation farmers are highly vulnerable to price shocks and the resultant decrease in income. Finally, it is important to stress that education significantly affects most of the dietary indicators and food expenditure, particularly in the non-adopters. This implies that the quality and diversity of these smallholders could be promoted through both education and awareness training.

\section{Impact of Oil Palm Adoption on Household Diets}

The next logical question, important for policy implications, is how the availability and diversity of food, quantities of fruits and vegetables consumed, and food expenditure would change if the non-adopters adopt oil palm or vice versa? This leads to the presentation of results from the counterfactual analyses. I have compared the actual dietary indicators of the oil palm adopters to the counterfactual dietary indicators of those farmers if they were non-adopters (ATT). Similarly, I have compared the actual dietary indicators of non-adopters with their counterfactual dietary indicators had they been cultivating oil palm (ATU). The dietary indicators are log transformed to be normally distributed and enable easy comparisons among the indicators. The results are presented in Table 4. Since the dietary indicators are in logarithmic form, I have interpreted the results in percentages. On average, I find that oil palm adopters would have fallen in calories, dietary diversity, quantities of fruits and vegetables consumed and food expenditure, if they become non-adopters by $11.0,12.6,16.5$, and $51.3 \%$, respectively. In contrast, the diets of non-adopters would have been higher than now if they had adopted oil palm. Specifically, had the non-adopters adopted oil palm, the diversity of their diets would have increased by 51.2 $\%$, and the daily quantities of fruits and vegetables consumed by $66.7 \%$, the daily calorie consumption by $31.4 \%$, and annual food expenditure by $45.3 \%$. Generally, these results show that non-adopters can significantly improve their diets in terms of 
TABLE 3 | Binary switching regression for oil palm adoption and impact on household diets and food expenditure.

\begin{tabular}{|c|c|c|c|c|c|c|c|c|c|c|c|c|}
\hline & \multicolumn{3}{|c|}{ Log HDDS (9 food groups) } & \multicolumn{3}{|c|}{ Log fruits and Vegetables (g/AE) } & \multicolumn{3}{|c|}{ Log calorie (kcal/AE) } & \multicolumn{3}{|c|}{ Log food expenditure per AE } \\
\hline & \multirow[b]{2}{*}{$\begin{array}{l}\text { Selection } \\
\text { (1) }\end{array}$} & \multicolumn{2}{|c|}{ Outcome } & \multirow[b]{2}{*}{$\begin{array}{l}\text { Selection } \\
\text { (4) }\end{array}$} & \multicolumn{2}{|c|}{ Outcome } & \multirow[b]{2}{*}{$\begin{array}{l}\text { Selection } \\
\text { (7) }\end{array}$} & \multicolumn{2}{|c|}{ Outcome } & \multirow[b]{2}{*}{$\begin{array}{l}\text { Selection } \\
\text { (10) }\end{array}$} & \multicolumn{2}{|c|}{ Outcome } \\
\hline & & $\begin{array}{l}\text { Adopter } \\
\text { (2) }\end{array}$ & $\begin{array}{c}\text { Non-adopters } \\
\text { (3) }\end{array}$ & & $\begin{array}{l}\text { Adopters } \\
\text { (5) }\end{array}$ & $\begin{array}{c}\text { Non-adopters } \\
\text { (6) }\end{array}$ & & $\begin{array}{l}\text { Adopters } \\
\text { (8) }\end{array}$ & $\begin{array}{l}\text { Non-adopters } \\
\text { (9) }\end{array}$ & & $\begin{array}{c}\text { Adopters } \\
\text { (11) }\end{array}$ & $\begin{array}{c}\text { Non-adopters } \\
\text { (12) }\end{array}$ \\
\hline \multirow[t]{2}{*}{ HH size } & 0.023 & 0.008 & $0.014^{\star \star \star}$ & 0.026 & 0.009 & $0.030^{\star}$ & 0.027 & $-0.085^{\star \star \star}$ & $-0.045^{\star \star \star}$ & 0.030 & $-0.097^{\star \star \star}$ & $-0.056^{\star \star \star}$ \\
\hline & $(0.023)$ & $(0.007)$ & (0.005) & $(0.024)$ & (0.022) & $(0.016)$ & (0.023) & $(0.012)$ & $(0.008)$ & $(0.024)$ & (0.013) & $(0.010)$ \\
\hline \multirow[t]{2}{*}{ Age of $\mathrm{HH}$ head } & -0.001 & -0.000 & -0.001 & -0.002 & -0.000 & 0.002 & -0.003 & 0.001 & 0.002 & -0.003 & -0.000 & $0.003^{\star \star}$ \\
\hline & $(0.003)$ & $(0.001)$ & $(0.001)$ & $(0.003)$ & $(0.003)$ & $(0.002)$ & $(0.003)$ & $(0.002)$ & $(0.001)$ & $(0.003)$ & $(0.002)$ & $(0.001)$ \\
\hline \multirow[t]{2}{*}{ Education of $\mathrm{HH}$ head } & 0.007 & 0.004 & $0.009^{\star \star \star}$ & 0.010 & 0.010 & $0.029^{\star \star \star}$ & 0.010 & -0.003 & $0.015^{\star \star \star}$ & 0.011 & 0.003 & $0.023^{\star \star \star}$ \\
\hline & $(0.010)$ & $(0.003)$ & $(0.002)$ & $(0.011)$ & $(0.010)$ & $(0.006)$ & $(0.011)$ & $(0.005)$ & $(0.004)$ & $(0.011)$ & $(0.006)$ & $(0.004)$ \\
\hline \multirow[t]{2}{*}{ HH owns business } & 0.096 & 0.005 & $0.029^{\star}$ & 0.135 & $0.184^{\star *}$ & 0.011 & 0.129 & $0.100^{* *}$ & 0.046 & 0.133 & $0.126^{\star \star \star}$ & $0.101^{\star \star}$ \\
\hline & $(0.079)$ & $(0.021)$ & $(0.017)$ & $(0.086)$ & $(0.077)$ & $(0.059)$ & $(0.086)$ & $(0.039)$ & $(0.030)$ & $(0.086)$ & $(0.045)$ & $(0.042)$ \\
\hline \multirow[t]{2}{*}{ Ethnicity: (1 = Melayu) } & $-0.147^{\star}$ & 0.002 & $-0.033^{\star \star}$ & $-0.186^{\star \star}$ & -0.078 & 0.007 & $-0.192^{\star \star}$ & 0.011 & -0.009 & $-0.178^{\star \star}$ & -0.035 & -0.056 \\
\hline & $(0.078)$ & $(0.022)$ & $(0.015)$ & $(0.083)$ & $(0.073)$ & $(0.049)$ & $(0.083)$ & $(0.040)$ & $(0.027)$ & $(0.083)$ & $(0.044)$ & $(0.035)$ \\
\hline \multirow[t]{2}{*}{ Cultivated land area } & $0.038^{\star \star \star}$ & $-0.003^{\star \star}$ & 0.002 & $0.043^{\star \star \star}$ & 0.004 & $0.020^{\star \star \star}$ & $0.043^{\star \star \star}$ & $0.005^{\star \star \star}$ & $0.016^{\star \star \star}$ & $0.045^{\star \star \star}$ & $0.009^{\star \star \star}$ & 0.011 \\
\hline & (0.010) & (0.001) & (0.001) & (0.012) & (0.004) & (0.005) & (0.012) & (0.002) & (0.004) & (0.013) & (0.003) & (0.007) \\
\hline \multirow[t]{2}{*}{ Titled land (\%) } & $0.342^{\star \star \star}$ & $-0.059^{\star \star}$ & $0.032^{*}$ & $0.394^{\star * \star}$ & -0.000 & $0.104^{*}$ & $0.388^{\star \star \star}$ & 0.051 & $0.070^{\star *}$ & $0.394^{\star \star \star}$ & 0.005 & 0.052 \\
\hline & $(0.085)$ & $(0.025)$ & $(0.017)$ & $(0.088)$ & $(0.104)$ & $(0.063)$ & $(0.089)$ & $(0.046)$ & $(0.033)$ & $(0.087)$ & $(0.049)$ & $(0.055)$ \\
\hline \multirow[t]{2}{*}{ Credit from formal source } & $0.408^{\star \star \star}$ & $-0.093^{\star \star \star}$ & -0.007 & $0.432^{\star \star \star}$ & -0.115 & $0.165^{\star \star \star}$ & $0.438^{\star \star \star}$ & -0.063 & $0.055^{\star}$ & $0.427^{\star \star \star}$ & -0.073 & -0.003 \\
\hline & $(0.075)$ & $(0.025)$ & $(0.017)$ & $(0.081)$ & $(0.087)$ & $(0.063)$ & $(0.081)$ & $(0.041)$ & $(0.034)$ & $(0.084)$ & $(0.046)$ & $(0.060)$ \\
\hline \multirow[t]{2}{*}{ Altitude } & $-0.005^{\star \star \star}$ & & & $-0.009^{\star \star \star}$ & & & $-0.009^{\star \star \star}$ & & & $-0.008^{\star \star \star}$ & & \\
\hline & $(0.001)$ & & & (0.002) & & & $(0.001)$ & & & $(0.002)$ & & \\
\hline \multirow[t]{2}{*}{ Dummy 2015} & -0.017 & 0.006 & 0.003 & -0.023 & $-0.660^{\star \star \star}$ & $-0.748^{\star \star \star}$ & -0.032 & $-0.092^{\star \star \star}$ & $-0.104^{\star \star \star}$ & -0.029 & $0.074^{\star}$ & 0.037 \\
\hline & (0.069) & $(0.019)$ & $(0.014)$ & $(0.076)$ & $(0.061)$ & $(0.045)$ & $(0.073)$ & (0.035) & $(0.024)$ & $(0.073)$ & (0.039) & $(0.030)$ \\
\hline \multirow[t]{2}{*}{ Constant } & $-0.591^{\star \star}$ & $2.202^{\star \star \star}$ & $1.744^{\star \star \star}$ & -0.355 & $6.543^{\star \star \star}$ & $5.558^{\star \star \star}$ & -0.323 & $8.443^{\star \star \star}$ & $7.792^{\star \star \star}$ & -0.415 & $9.344^{\star \star \star}$ & $8.374^{\star \star \star}$ \\
\hline & $(0.244)$ & $(0.069)$ & $(0.046)$ & $(0.250)$ & $(0.328)$ & $(0.143)$ & $(0.248)$ & $(0.148)$ & $(0.077)$ & $(0.268)$ & $(0.158)$ & $(0.112)$ \\
\hline \multirow[t]{2}{*}{$\Sigma_{a}$} & & $0.269^{\star \star \star}$ & & & $0.698^{\star \star \star}$ & & & 0.399 & & & $0.441^{\star * \star}$ & \\
\hline & & $(0.022)$ & & & $(0.056)$ & & & 0.022 & & & $(0.024)$ & \\
\hline \multirow[t]{2}{*}{$\Sigma_{n}$} & & & $0.208^{\star \star \star}$ & & & $0.655^{\star \star \star}$ & & & $0.363^{\star \star \star}$ & & & $0.465^{\star \star \star}$ \\
\hline & & & $(0.007)$ & & & $(0.022)$ & & & $(0.016)$ & & & $(0.030)$ \\
\hline$\rho_{a}$ & & $-0.958^{\star \star \star}$ & & & $-0.432^{\star \star}$ & & & $-0.393^{\star \star}$ & & & $-0.433^{\star \star \star}$ & \\
\hline & & $(0.020)$ & & & $(0.209)$ & & & 0.156 & & & $(0.147)$ & \\
\hline$\rho_{\mathrm{n}}$ & & & $-0.246^{\star \star \star}$ & & & -0.214 & & & -0.320 & & & $-0.652^{\star \star \star}$ \\
\hline & & & $(0.046)$ & & & $(0.148)$ & & & $(0.211)$ & & & $(0.129)$ \\
\hline Wald test on exclusion res & iction variable & altitude: & & & & & & & & & & \\
\hline & & $x^{2}=0.0$ & & & $x^{2}=0.0$ & & & $x^{2}=0.0$ & & & $x^{2}=0.0$ & \\
\hline Observation & & 1378 & & & 1378 & & & 1378 & & & $137 \varepsilon$ & \\
\hline
\end{tabular}

Coefficients are shown with standard errors in parentheses. HDDS, household dietary diversity score; HH, household. Subscript a and $n$ denote adopters and non-adopters, respectively. *, **, *** denote significance at 10, 5 , and 1\% levels, respectively. 
TABLE 4 | Treatment effects of oil palm adoption.

\begin{tabular}{|c|c|c|c|c|c|}
\hline \multirow{2}{*}{$\begin{array}{l}\text { Variables } \\
\text { Log HDDS (9 food groups) }\end{array}$} & \multirow{2}{*}{$\begin{array}{l}\text { Household type } \\
\text { Adopters }\end{array}$} & \multirow{2}{*}{$\begin{array}{c}\text { Adopters } \\
1.925\end{array}$} & \multirow{2}{*}{$\begin{array}{c}\text { Non-adopters } \\
1.820\end{array}$} & \multicolumn{2}{|c|}{ Treatment effects } \\
\hline & & & & $0.126^{\star \star \star}$ & ATT \\
\hline & & $(0.002)$ & $(0.003)$ & $(0.002)$ & \\
\hline & Non-adopters & 2.374 & 1.862 & $0.512^{\star \star \star}$ & ATU \\
\hline & & $(0.001)$ & $(0.002)$ & $(0.001)$ & \\
\hline \multirow[t]{4}{*}{ Log fruits and vegetables (g/AE/day) } & Adopters & 6.025 & 5.856 & $0.168^{\star \star \star}$ & ATT \\
\hline & & $(0.016)$ & $(0.020)$ & $(0.009)$ & \\
\hline & Non-adopters & 6.460 & 5.793 & $0.667^{\star \star \star}$ & ATU \\
\hline & & $(0.012)$ & $(0.014)$ & $(0.005)$ & \\
\hline \multirow[t]{4}{*}{ Log calorie (kcal/AE/day) } & Adopters & 8.005 & 7.895 & $0.110^{\star \star \star}$ & ATT \\
\hline & & $(0.007)$ & $(0.009)$ & $(0.006)$ & \\
\hline & Non-adopters & 8.164 & 7.850 & $0.314^{\star \star \star}$ & ATU \\
\hline & & (0.005) & (0.005) & (0.004) & \\
\hline \multirow[t]{4}{*}{ Log food expenditure (000 IDR/AE/year) } & Adopters & 8.858 & 8.345 & $0.513^{\star \star \star}$ & ATT \\
\hline & & (0.009) & $(0.010)$ & $(0.005)$ & \\
\hline & Non-adopters & 9.100 & 8.647 & $0.453^{\star \star \star}$ & ATU \\
\hline & & $(0.006)$ & $(0.007)$ & $(0.004)$ & \\
\hline
\end{tabular}

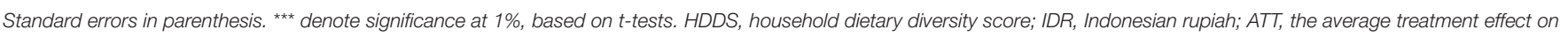
the treated; ATU, the average treatment effect on the untreated.

diversity, availability, and the consumption of micronutrients if they adopt oil palm.

\section{Robustness Checks and Dealing With Endogeneity}

As mentioned above, many of the adopters received oil palm plantations as part of the package of the transmigration program. This might bias impact estimates if not considered. Since the sampling strategy is random at the district, village, and household levels, and since I also use an econometric strategy that controls selection bias, this should not be a concern. However, as a robustness check, I have re-estimated all models by restricting the sample solely to the local communities. That is, I have excluded the transmigrant households from the estimation models. Results for the exclusion restriction test are presented in Table A1 in the Supplementary Material, while results from the switching regression estimation in a counterfactual framework are shown in Tables A2 and A3 in the Supplementary Material. The results tell a similar story as to those estimates in Tables 3, 4. Indeed, regardless of a household's background, being from transmigrant or local communities, adopting oil palm improves household diets significantly.

Moreover, in the analyses so far I have not considered whether previous income (the wealth status of a farmer before adopting oil palm) affects the dietary benefits and oil palm adoption simultaneously; so it not yet clear whether the observed effects are actually due to oil palm adoption. In econometric terms, is there an endogeneity (reverse causality) problem in the data I use in this study? In order to test whether previous income status changes the findings, one needs to have income information of the two groups of adopters and non-adopters before 2012, that is, before the first wave of the dataset used in this study was collected. Unfortunately, such information is not available in this dataset. However, the CRC 990/EFForTS project is still tracking the sample households; and out of the 440 households that were non-adopters in 2012, 83 households have so far adopted oil palm [24 households adopted between 2012 (as mentioned earlier) and 2015 and another 59 households between 2015 and 2018]. I have therefore examined whether the average annual income and total expenditure in 2012 differ between the new adopters and those who have not yet adopted oil palm. The logic behind is that if the average annual income and expenditure differ between these two subsamples, there is highly likely that the average income and expenditure in the adopters and non-adopters in the whole dataset to be different as well. The estimated results are shown in Table A4 in the Supplementary Material. The findings show that there is no statistically significant difference between the two groups. This implies that the adopters were not wealthier than the non-adopters in 2012, and thus the observed effects on dietary outcomes are actually due to oil palm adoption. Besides, the majority of the adopters in the dataset I use in this study are transmigrant households who received oil palm plantations from the government (and as explained above, this difference is effectively dealt using appropriate econometric estimation model). Those transmigrant households did have noticeable wealth when they arrived in Sumatra; they were actually under food aid for several years (Fearnside, 1997). In other words, households in Jambi are adopting oil palm by the prospect to improve welfare (dietary outcomes), but it is unlikely that a priori wealth status systematically derives the observed dietary benefits in the adopters. Against this background, I conclude that reverse causality is not a problem in the data I use in this study.

\section{Effects of Oil Palm Adoption on Food and Nutritional Adequacy}

In the final analysis, I present and discuss the effects of oil palm adoption on food and micronutrient adequacy. I mainly discuss the impact of oil palm adoption on the mean 
TABLE 5 | Effects of oil palm adoption on household diet outcomes.

\begin{tabular}{|c|c|c|c|c|c|c|}
\hline & $\begin{array}{c}\text { (1) } \\
\text { Fruits and vegetable } \\
\text { adequacy }\end{array}$ & $\begin{array}{c}\text { (2) } \\
\text { Calorie } \\
\text { adequacy }\end{array}$ & $\begin{array}{c}\text { (3) } \\
\text { Iron } \\
\text { adequacy }\end{array}$ & $\begin{array}{c}\text { (4) } \\
\text { Zinc } \\
\text { adequacy }\end{array}$ & $\begin{array}{c}\text { (5) } \\
\text { Vitamin A } \\
\text { adequacy }\end{array}$ & $\begin{array}{c}(6) \\
\text { Mean micronutrient } \\
\text { adequacy }\end{array}$ \\
\hline \multirow[t]{2}{*}{ Oil palm dummy (dummy) } & $0.336^{\star \star}$ & $0.386^{\star \star \star}$ & $0.364^{\star \star \star}$ & $0.549^{\star \star \star}$ & $0.331^{\star \star \star}$ & $0.350^{\star \star \star}$ \\
\hline & $(0.131)$ & $(0.132)$ & $(0.125)$ & $(0.175)$ & $(0.126)$ & $(0.130)$ \\
\hline \multirow[t]{2}{*}{$\mathrm{HH}$ size } & -0.026 & $-0.320^{\star \star \star}$ & $-0.182^{\star \star \star}$ & $-0.177^{\star \star \star}$ & $-0.136^{\star \star \star}$ & $-0.194^{\star \star \star}$ \\
\hline & $(0.039)$ & $(0.040)$ & $(0.039)$ & $(0.060)$ & $(0.039)$ & $(0.038)$ \\
\hline \multirow[t]{2}{*}{ Age of $\mathrm{HH}$ head } & $0.013^{\star \star}$ & 0.002 & 0.001 & 0.012 & 0.001 & -0.004 \\
\hline & $(0.006)$ & $(0.005)$ & $(0.005)$ & $(0.008)$ & $(0.005)$ & $(0.005)$ \\
\hline \multirow[t]{2}{*}{ Education of $\mathrm{HH}$ head } & $0.051^{\star \star \star}$ & $0.051^{\star \star *}$ & 0.024 & 0.030 & $0.092^{* \star *}$ & $0.067^{\star \star \star}$ \\
\hline & $(0.018)$ & $(0.018)$ & $(0.017)$ & $(0.025)$ & $(0.018)$ & $(0.018)$ \\
\hline \multirow[t]{2}{*}{ HH owns business } & $0.489^{\star \star \star}$ & $0.450^{\star \star \star}$ & $0.293^{\star \star}$ & 0.168 & $0.376^{\star \star \star}$ & $0.362^{\star \star}$ \\
\hline & $(0.144)$ & $(0.146)$ & $(0.137)$ & (0.192) & $(0.137)$ & $(0.143)$ \\
\hline \multirow[t]{2}{*}{ Ethnicity: (1 = Melayu) } & 0.062 & 0.189 & 0.127 & -0.051 & -0.171 & -0.099 \\
\hline & $(0.150)$ & $(0.149)$ & $(0.146)$ & $(0.213)$ & $(0.144)$ & $(0.147)$ \\
\hline \multirow[t]{2}{*}{ Cultivated land area } & $0.029^{\star \star}$ & $0.058^{\star \star \star}$ & $0.048^{\star \star \star}$ & $0.048^{\star \star \star}$ & $0.058^{\star \star \star}$ & $0.082^{\star \star \star}$ \\
\hline & $(0.011)$ & $(0.017)$ & $(0.013)$ & $(0.011)$ & $(0.014)$ & $(0.018)$ \\
\hline \multirow[t]{2}{*}{ Titled land (\%) } & $0.346^{\star \star}$ & 0.163 & $0.421^{\star \star \star}$ & 0.289 & $0.386^{\star \star \star}$ & $0.420^{\star \star \star}$ \\
\hline & $(0.157)$ & $(0.154)$ & $(0.149)$ & $(0.218)$ & $(0.149)$ & $(0.153)$ \\
\hline \multirow[t]{2}{*}{ Migrant: ( 1 = transmigrant) } & -0.092 & 0.135 & 0.207 & 0.287 & -0.147 & -0.034 \\
\hline & $(0.169)$ & $(0.168)$ & $(0.161)$ & $(0.222)$ & $(0.162)$ & $(0.167)$ \\
\hline \multirow[t]{2}{*}{ Credit from formal source } & $0.261^{\star}$ & $0.323^{\star \star}$ & 0.143 & $0.373^{\star \star}$ & 0.028 & 0.081 \\
\hline & $(0.140)$ & $(0.139)$ & $(0.132)$ & $(0.181)$ & $(0.132)$ & $(0.137)$ \\
\hline \multirow[t]{2}{*}{ Dummy 2015} & $-1.730^{\star \star \star}$ & $-0.401^{\star \star \star}$ & $-0.512^{\star \star \star}$ & $-0.440^{\star \star \star}$ & $-0.333^{\star \star \star}$ & $-0.547^{\star \star \star}$ \\
\hline & $(0.125)$ & $(0.119)$ & $(0.117)$ & $(0.170)$ & $(0.116)$ & $(0.118)$ \\
\hline Observations & 1378 & 1378 & 1378 & 1378 & 1378 & 1378 \\
\hline Prob $\times 2$ & $0.000^{\star \star \star}$ & $0.000^{\star \star \star}$ & $0.000^{\star \star \star}$ & $0.000^{\star \star \star}$ & $0.000^{\star \star \star}$ & $0.000^{\star \star \star}$ \\
\hline
\end{tabular}

Marginal effects after panel logit regression are shown with standard errors in parentheses. $H H$, household. *, ${ }^{* *},{ }^{* *}$ denote significance at 10,5 , and $1 \%$ levels, respectively.

probability of adequacy of fruits and vegetables consumed, calories, iron, zinc, vitamin $\mathrm{A}$, and the average of the three micronutrients. The estimated results of the panel logit models are presented in Table 5. Since the estimated coefficients are reported in marginal effects at mean values, I have interpreted the results in percentages. Regardless of the diet indicator, oil palm adoption has statistically significant and positive effects, indicating that oil palm cultivation leads to higher food and micronutrient adequacy in general. On an average, the adoption of oil palm increases the probability of consuming fruits and vegetables by $33.6 \%$, calorie adequacy by $38.6 \%$, iron adequacy by 36.4 , zinc adequacy by $54.9 \%$, vitamin A adequacy by $33.1 \%$, and average adequacy of the three micronutrients by $35 \%$.

Together, with the results from the endogenous switching regression, it can be deduced that oil palm adoption improves the diets of farm households in the tropics, whether they belong to the transmigrant or the local communities. Hence, the nutritional impact might justify why farm households in the tropical are rapidly expanding oil palm cultivation. Moreover, several socioeconomic, farm, and demographic factors impact oil palm adoption and, at the same time, shape the diversity and adequacy of diets in those households.

\section{CONCLUSION}

I have analyzed the dietary impacts of oil palm adoption in farm households of the tropics, which has received little attention in the existing literature. In particular, using panel farm household data from Jambi province on the island of Sumatra, Indonesia, the effects of oil palm adoption on dietary diversity, quantities of fruits and vegetables consumed, calories, and food expenditure have been examined. Endogenous switching regression is applied to control for selection bias and to obtain counterfactual outcomes. Also, using panel logit regression estimation, I have examined the impact of oil palm adoption on dichotomous variables of household's diets, indicating whether the diet met the minimum adequacy level of fruits and vegetables consumed, calorie, iron, zinc, vitamin A, and the average of the three micronutrients. Rather than support the idea that adopting a perennial and non-food commercial crop worsens dietary quality and diversity in farm households, my findings support the opposite. The results illustrate that land-use change through oil palm adoption significantly improves the diets of farm households in the tropics. Positive effects are observed, notwithstanding, whether households belong to transmigrant or local communities. 
Notably, oil palm adopters consume more diverse foods than non-adopters. The prevalence of undernourishment and micronutrient inadequacies are significantly less in such households. I also find that oil palm significantly increases household dietary diversity, food availability, food expenditure, and the adequacy of micronutrients through the income pathway. Furthermore, several socioeconomic, farm related, and demographic factors influence both oil palm adoption and the diversity and adequacy of household diets. This impact, leading to better diets, however, is complex and not straightforward; several the socioeconomic, demographic, and farm factors have different dietary impacts for adopters and non-adopters, which indicates that dietary diversity and quality in farm households should be promoted through strategies specifically tailored to the needs of these households.

Beyond the possible dietary impacts of oil palm adoption and the confounding factors, the findings also show that diets of farm household in the tropics are highly vulnerable to price and income shocks; the diets in both types of households were worse in 2015 than in 2012, as a consequence of the global drop in prices of oil palm and rubber. Moreover, oil palm is more capital-intensive as compared to the labor-intensive rubber, rice, or alternative crops cultivated in the tropics. This implies that expansion of the crop in smallholder setting of the rural tropics releases more labor to the rural labor market; women and older people might be more affected as they are less likely to work in oil palm plantations (Kubitza et al., 2018). Thus, creating off-farm work opportunities might help address issues related to price and income shocks, as well as to absorb the excess rural labor released because of the expansion of oil palm in the tropical rural areas.

In sum, the findings suggest that smallholder farmers seem to adopt and expand land-use types that provide greater dietary benefits. From a policy perspective, policy-makers interested in maintaining the tropical rainforests, regulating oil palm plantations and tackling nutritional deficiencies in the tropics should not overlook these dietary benefits for farm households.

I conclude by highlighting a few limitations that might be beneficial in future research. The focus of this study is to better understand the impact of oil palm adoption through the agricultural income pathway, not to capture all potential impact pathways. Future studies should, therefore, identify and investigate other impact pathways on how oil palm adoption influences household diets. Moreover, I have used a statistically valid selection instrument to account for selection bias as well as have tested for possible endogeneity issues. However, this is not to claim that the selection instrument used and the endogeneity tested in this paper are absolutely perfect. Yet this still helps to reduce the level of the statistical endogeneity problem often faced in this kind of study by reducing the level of bias in analyzing the dietary and nutritional impacts of oil palm adoption in the tropics. Similarly, I note that the results here reflect the situation in Jambi and may not be generalized. Followup research might test with data from other regions and use different estimation techniques to increase the reliability of the findings in this study. Finally, household-level dietary indicators are used in this study. Household-level food consumption is the entry point for any policy that targets individuals because a person can access and consume only the foods present in her/his household. Recent evidence also supports that householdlevel food consumption is strongly correlated with individuallevel dietary intakes. However, it remains to be studied about how household-level food consumption could be proxy for the mean probability of adequacy of micronutrients in multi-site quantitative datasets.

\section{DATA AVAILABILITY}

The dataset analyzed for this study can be openly accessible from EFForTs-Information System: University of Goettingen (https:// efforts-is.uni-goettingen.de).

\section{ETHICS STATEMENT}

Oral informed consent was obtained from village heads and all respondents before the survey was implemented. All study participants were informed that any information collected was to remain confidential and solely used for research purpose. Every identifying datum was also anonymized in the final dataset used for the analyses. As per the Collaborative German-Indonesian Research Project CRC990 and national guidelines, written legal consent from study participates were not required.

\section{AUTHOR CONTRIBUTIONS}

The author confirms being the sole contributor of this work and has approved it for publication.

\section{FUNDING}

This study was funded by the Deutsche Forschungsgemeinschaft (DFG, German Research Foundation)-project number 192626868-SFB 990 in the framework of the collaborative German-Indonesian research project CRC990.

\section{ACKNOWLEDGMENTS}

I thank Matin Qaim, Hermanto Siregar, and the two reviewers of this journal for their valuable comments on previous versions of this manuscript. I am grateful to Zulkifli Alamsyah for his support and cooperation. Thanks also to my CRC 990-C07 colleagues for their useful comments on an earlier version of this manuscript. Fruitful cooperation with Bogor Agricultural University (IPB) and University of Jambi (UNJA) is gratefully acknowledged. All remaining errors are mine.

\section{SUPPLEMENTARY MATERIAL}

The Supplementary Material for this article can be found online at: https://www.frontiersin.org/articles/10.3389/fsufs. 2019.00075/full\#supplementary-material 


\section{REFERENCES}

Berger, J., Blanchard, G., Ponce, M. C., Chamnan, C., Chea, M., Dijkhuizen, M., et al. (2013). The SMILING project: a North-South-South collaborative action to prevent micronutrient deficiencies in women and young children in Southeast Asia. Food Nutr. Bull. 34, S133-S139. doi: $10.1177 / 15648265130342 S 115$

Black, R. E. (2014). Global distribution and disease burden related to micronutrient deficiencies. Nestle Nutr. Inst. Workshop Ser. 78, 21-28. doi: 10.1159/000354932

BPS (2017). Badan Pusat Statistik. Jambi: Statistical Office of Jambi Province. BPS (2018). Badan Pusat Statistik. Jambi: Statistical Office of Jambi Province.

Byerlee, D., Falcon, W. P., and Naylor, R. L. (2017). The Tropical Oil Crop Revolution: Food, Feed, Fuel, and Forests. New York, NY: Oxford University Press.

Byerlee, D., and Viswanathan, P. K. (2018). "Plantations and economic development in the twentieth century: the end of an era?" in Agricultural Development in the World Periphery: A Global Economic History Approach, eds V. Pinilla, and H. Willebald (Cham: Springer International Publishing), 89-117.

Carter, D. W., and Milon, J. W. (2005). Price knowledge in household demand for utility services. Land Econ. 81, 265-283. doi: 10.3368/le.81.2.265

Chrisendo, D., Krishna, V., Siregar, H., and Qaim, M. (2019). "Land-use change, nutrition, and gender roles in Indonesian farm households," in EFForTS Discussion Paper Series Nr. 24. (Goettingen).

Clough, Y., Krishna, V. V., Corre, M. D., Darras, K., Denmead, L. H., Meijide, A., et al. (2016). Land-use choices follow profitability at the expense of ecological functions in Indonesian smallholder landscapes. Nat. Commun. 7:13137. doi: $10.1038 /$ ncomms13137

Daulay, A. R., Eka Intan, K. P., Barus, B., and Pramudya, N. B. (2016). Rice land conversion into plantation crop and challenges on sustainable land use system in the East Tanjug Jabung Regency. Proc. Soc. Behav. Sci. 227, 174-180. doi: 10.1016/j.sbspro.2016.06.059

de Haen, H., Klasen, S., and Qaim, M. (2011). What do we really know? Metrics for food insecurity and undernutrition. Food Policy 36, 760-769. doi: 10.1016/j.foodpol.2011.08.003

Dewi, S., Belcher, B., and Puntodewo, A. (2005). Village economic opportunity, forest dependence, and rural livelihoods in East Kalimantan, Indonesia. World Dev. 33, 1419-1434. doi: 10.1016/j.worlddev.2004.10.006

Di Falco, S., Veronesi, M., and Yesuf, M. (2011). Does adaptation to climate change provide food security? A micro-perspective from Ethiopia. Am. J. Agric. Econ. 93, 829-846. doi: 10.1093/ajae/aar006

DJP (2017). Statistik Perkebunan Indonesia; Tree Crop Estate Statistics of Indonesia: Kelapa Sawit 2015-2017. Jakarta: Direktorat Jenderal Perkebunan.

Drescher, J., Rembold, K., Allen, K., Beckschäfer, P., Buchori, D., Clough, Y., et al. (2016). Ecological and socio-economic functions across tropical land use systems after rainforest conversion. Philos. Trans. R. Soc. Lond. B Biol. Sci. 371:20150275. doi: 10.1098/rstb.2015.0275

Euler, M., Hoffmann, M. P., Fathoni, Z., and Schwarze, S. (2016). Exploring yield gaps in smallholder oil palm production systems in eastern Sumatra, Indonesia. Agric. Syst. 146, 111-119. doi: 10.1016/j.agsy.2016.04.007

Euler, M., Krishna, V., Schwarze, S., Siregar, H., and Qaim, M. (2017). Oil palm adoption, household welfare, and nutrition among smallholder farmers in Indonesia. World Dev. 93, 219-235. doi: 10.1016/j.worlddev.2016.12.019

FAO (1990). The Oil Palm. Rome.

FAO (2001). Human Energy Requirements. Rome.

FAO (2018). FAOSTAT. Available online at: http://faostat.fao.org/site/339/default. aspx (accessed March 22, 2019).

FAO, and FHI 360 (2016). Minimum Dietary Diversity for Women- A Guide to Measurement. Rome.

FAO, and WHO (2014). National Nutrition Strategy paper of Indonesia: Second International Conference on Nutrition (ICN 2). Rome.

FAO, WHO, and UNU (2004). Human Energy Requirements: Report of a Joint FAO/WHO/UNU Expert Consultation. Rome, 17-24 October 2001. Rome.

Fearnside, P. M. (1997). Transmigration in Indonesia: lessons from its environmental and social impacts. Environ. Manage. 21, 553-570. doi: $10.1007 /$ s002679900049

Fongar, A., Gödecke, T., Aseta, A., and Qaim, M. (2019). How well do different dietary and nutrition assessment tools match? Insights from rural Kenya. Public Health Nutr. 22, 391-403. doi: 10.1017/S1368980018002756
Foster, W. A., Snaddon, J. L., Turner, E. C., Fayle, T. M., Cockerill, T. D., Ellwood, M. D. F., et al. (2011). Establishing the evidence base for maintaining biodiversity and ecosystem function in the oil palm landscapes of South East Asia. Philos. Trans. R. Soc. Lond. B Biol. Sci. 366, 3277-3291. doi: 10.1098/rstb.2011.0041

Frelat, R., Lopez-Ridaura, S., Giller, K. E., Herrero, M., Douxchamps, S., Andersson Djurfeldt, A., et al. (2016). Drivers of household food availability in sub-Saharan Africa based on big data from small farms. Proc. Natl. Acad. Sci. U.S.A. 113, 458-463. doi: 10.1073/pnas.1518384112

Gatto, M., Wollni, M., Asnawi, R., and Qaim, M. (2017). Oil palm boom, contract farming, and rural economic development: village-level evidence from Indonesia. World Dev. 95, 127-140. doi: 10.1016/j.worlddev.2017.02.013

Gatto, M., Wollni, M., and Qaim, M. (2015). Oil palm boom and land-use dynamics in Indonesia: the role of policies and socioeconomic factors. Land Use Policy 46, 292-303. doi: 10.1016/j.landusepol.2015.03.001

Hatløy, A., Torheim, L. E., and Oshaug, A. (1998). Food variety-a good indicator of nutritional adequacy of the diet? A case study from an urban area in Mali, West Africa. Eur. J. Clin. Nutr. 52, 891-898. doi: 10.1038/sj.ejcn.1600662

Heckman, J., Tobias, J. L., and Vytlacil, E. (2001). Four parameters of interest in the evaluation of social programs. South. Econ. J. 68:210. doi: 10.2307/1061591

Hidayat, N. K., Offermans, A., and Glasbergen, P. (2018). Sustainable palm oil as a public responsibility? On the governance capacity of Indonesian standard for sustainable palm oil (ISPO). Agric. Human Values 35, 223-242. doi: 10.1007/s10460-017-9816-6

Ickowitz, A., Rowland, D., Powell, B., Salim, M. A., and Sunderland, T. (2016). Forests, trees, and micronutrient-rich food consumption in Indonesia. PLoS ONE 11:e0154139. doi: 10.1371/journal.pone.0154139

Isabelle, M., and Chan, P. (2011). Seminar on young child nutrition: improving nutrition and health status of young children in Indonesia. Asia Pac. J. Clin. Nutr. 20, 141-147.

Krishna, V. V., Euler, M., Siregar, H., and Qaim, M. (2017a). Differential livelihood impacts of oil palm expansion in Indonesia. Agric. Econ. 48, 639-653. doi: 10.1111/agec.12363

Krishna, V. V., Kubitza, C., Pascual, U., and Qaim, M. (2017b). Land markets, property rights, and deforestation: insights from Indonesia. World Dev. 99, 335-349. doi: 10.1016/j.worlddev.2017.05.018

Kubitza, C., Krishna, V. V., Alamsyah, Z., and Qaim, M. (2018). The economics behind an ecological crisis: livelihood effects of oil palm expansion in Sumatra, Indonesia. Hum. Ecol. 46, 107-116. doi: 10.1007/s10745-017-9965-7

Li, T. M. (2015). "Social impacts of oil palm in Indonesia: a gendered perspective from West Kalimantan," in Occasional Paper 124 (Bogor: Center for International Forestry Research).

Lo, Y. T., Chang, Y. H., Lee, M. S., and Wahlqvist, M. L. (2012). Dietary diversity and food expenditure as indicators of food security in older Taiwanese. Appetite 58, 180-187. doi: 10.1016/j.appet.2011.09.023

Lokshin, M., and Sajaia, Z. (2004). Maximum likelihood estimation of endogenous switching regression models. Stata J. 4, 282-289. doi: $10.1177 / 1536867 X 0400400306$

Luskin, M. S., Christina, E. D., Kelley, L. C., and Potts, M. D. (2014). Modern hunting practices and wild meat trade in the oil palm plantationdominated landscapes of Sumatra, Indonesia. Hum. Ecol. 42, 35-45. doi: 10.1007/s10745-013-9606-8

Margono, B. A., Potapov, P. V., Turubanova, S., Stolle, F., and Hansen, M. C. (2014). Primary forest cover loss in Indonesia over 2000-2012. Nat. Clim. Change 4, 730-735. doi: 10.1038/nclimate2277

Martin-Prével, Y., Allemand, P., Wiesmann, D., Arimond, M., Ballard, T., Deitchler, M., et al. (2015). Moving Forward on Choosing a Standard Operational Indicator of Women's Dietary Diversity. Rome: Food and Agriculture Organization.

Overbeek, W., Kröger, M., and Gerber, J. F. (2012). An Overview of Industrial Tree Plantation Conflicts in the Global South: Conflicts, Trends, and Resistance Struggles. EJOLT Report No. 03, Autonomous University of Barcelona.

Rist, L., Feintrenie, L., and Levang, P. (2010). The livelihood impacts of oil palm: smallholders in Indonesia. Biodivers. Conserv. 19, 1009-1024. doi: 10.1007/s10531-010-9815-z

Ruel, M. T. (2003). Operationalizing dietary diversity: a review of measurement issues and research priorities. J. Nutr. 133, 3911S-3926S. doi: $10.1093 / \mathrm{jn} / 133.11 .3911 \mathrm{~S}$ 
Sibhatu, K. T., Krishna, V. V., and Qaim, M. (2015). Production diversity and dietary diversity in smallholder farm households. Proc. Natl. Acad. Sci. U.S.A. 112, 10657-10662. doi: 10.1073/pnas.1510982112

Sibhatu, K. T., and Qaim, M. (2017). Rural food security, subsistence agriculture, and seasonality. PLoS ONE 12:e0186406. doi: 10.1371/journal.pone.0186406

Sibhatu, K. T., and Qaim, M. (2018). Farm production diversity and dietary quality: linkages and measurement issues. Food Secur. 10, 47-59. doi: 10.1007/s12571-017-0762-3

Sunderlin, W. D., Dewi, S., Puntodewo, A., Müller, D., Angelsen, A., and Epprecht, M. (2008). Why forests are important for global poverty alleviation: a spatial explanation. Ecol. Soc. 13:24. doi: 10.5751/ES-02590-130224

Sununtnasuk, C., and Fiedler, J. L. (2017). Can household-based food consumption surveys be used to make inferences about nutrient intakes and inadequacies? A Bangladesh case study. Food Policy 72, 121-131. doi: 10.1016/j.foodpol.2017.08.018

Susanti, A., and Budidarsono, S. (2014). "Land governance and oil palm development: examples from Riau Province, Indonesia, in the global land grab: beyond the hype," in The Global Land Grab: Beyond the Hype/Edited by Mayke Kaag and Annelies Zoomers, eds. M. M. A. Kaag, and E. B. Zoomers (London: Zed Books), 119-132.

Tscharntke, T., Leuschner, C., Veldkamp, E., Faust, H., Guhardja, E., and Bidin, A. (2010). Tropical Rainforests and Agroforests Under Global Change: Ecological and Socio-economic Valuations. Berlin, Heidelberg: Springer Berlin Heidelberg.
USDA (2005). Composition of Foods, Raw, Processed, Prepared, National Nutrient Database for Standard References, Release 18. Washington, DC: United States Department of Agriculture.

Wilcove, D. S., Giam, X., Edwards, D. P., Fisher, B., and Koh, L. P. (2013). Navjot's nightmare revisited: logging, agriculture, and biodiversity in Southeast Asia. Trends Ecol. Evol. 28, 531-540. doi: 10.1016/j.tree.2013.04.005

Wooldridge, J. M. (2010). Econometric Analysis of Cross Section and Panel Data. Cambridge, Mass., London: MIT.

Zen, Z., Barlow, C., and Gondowarsito, R. (2005). Oil Palm in Indonesian Socio-economic Improvement: A Review of Options. Working Papers in Trade and Development. Canberra: Research School of Pacific and Asian Studies, Australian National University.

Conflict of Interest Statement: The author declares that the research was conducted in the absence of any commercial or financial relationships that could be construed as a potential conflict of interest.

Copyright (C) 2019 Sibhatu. This is an open-access article distributed under the terms of the Creative Commons Attribution License (CC BY). The use, distribution or reproduction in other forums is permitted, provided the original author(s) and the copyright owner(s) are credited and that the original publication in this journal is cited, in accordance with accepted academic practice. No use, distribution or reproduction is permitted which does not comply with these terms. 